\title{
How Shall We Fashion International Legal Goals and Criteria for Appraisal in a World of Many Civilizations and Cultures? Review of Onuma Yasuaki's International Law in a Transcivilizational World
}

\author{
W. Michael REISMAN* \\ Yale Law School, the United States of America \\ michael.reisman@yale.edu \\ Tomo B. TAKAKI** \\ Yale Law School, the United States of America \\ tomo.takaki@yale.edu
}

Given his pride in the civilization which has nurtured him, Onuma Yasuaki would, we assume, be content to be introduced as the leading Japanese international legal scholar. We resist such a classification because it is unfair to him, inasmuch as it diminishes his standing and achievement by confining the comparators to one state; Onuma is simply a great international legal scholar and intellectual thought leader who happens to be Japanese. His many books, papers, and, now, the treatise under review confirm it. But yet another matter is his thesis that the intellectual task of clarifying values as goals for future law-making as well as for appraising current decisions should be steeped in all the great civilizations to ensure that their insights are taken into account. Writing from New Haven, our accord with Professor Onuma's identification of the problem will be no surprise: we endorse the intellectual task of the clarification of goals as a central responsibility of the contemporary international lawyer but we reject a problem-solving methodology that focuses on the values of a few cultures and civilizations for comparative and integrative purposes. That said, to do justice to Onuma's magnificent achievement with its many insights, and to locate our disagreement in only one part of his intellectual edifice, we will first survey and then comment on the main themes of his book before turning to his transcivilizationist thesis and his ambivalence toward what he refers to as the "West".

I.

In Chapter I, Professor Onuma lays the groundwork for his conception of an international community that enforces laws through social norms. Critical to this task is a

$* \quad$ Myres McDougal Professor of International Law, Yale Law School.
$* \quad \quad$ J.D. Candidate, Yale Law School. 
transcivilizational legitimacy which transcends the Euro-centric assumption of universality. He uses Chinese and Islamic universalistic belief systems to illustrate examples of historical rivals which were eventually shunted aside in favour of European international law. ${ }^{\mathrm{I}}$ In Chapter 2, Onuma delves into the processes of how international legal norms are socially constructed. ${ }^{2}$ In Chapter 3 , Onuma reviews key concepts of international law through the transcivilizationist lens to highlight important factors such as the upcoming "period of sovereignization" in non-Western states ${ }^{3}$ and the influence of nonstate participants in international law. ${ }^{4}$ Chapter 4 explains how violations of legal norms result in a range of both formal and informal responses by various participants. ${ }^{5}$ Chapter 5 then explores the spatial and personal ordering of the international system through nationality laws ${ }^{6}$ and the resolution of territorial and maritime disputes. ${ }^{7}$ In all of these arenas, Professor Onuma asserts that the transcivilizationist perspective is sorely needed. ${ }^{8}$

In Chapter 6, he applies this critique to human rights, arguing for a more comprehensive conception of international human rights instruments and non-discrimination law. ${ }^{9}$ In Chapter 7, Onuma's overview of the free trade economic system contained within the World Trade Organization and international investment agreements argues for the illegitimacy of the current and dominant deregulatory ideology, ${ }^{\text {IO }}$ though he acknowledges some of its benefits. Chapter 8 applauds the consensus emerging in international environmental law towards a universal duty to protect the environment (including cultural environs). ${ }^{\text {II }}$ But Onuma bemoans the much work yet to be completed, especially in addressing climate change. ${ }^{\mathrm{I} 2}$

In Chapter 9, Professor Onuma expansively covers conflict resolution mechanisms including arbitration, the International Court of Justice, and the UN. In the final Chapter Io, the UN takes particular pre-eminence as the cornerstone of the international system regulating the use of force. Here, Onuma analyzes the bases for justifying decisions to use force, such as individual and collective self-defence, counter-measures, peacekeeping, and humanitarian interventions, in keeping with his transcivilizationist thesis.

II.

The thread connecting the main themes throughout Professor Onuma's treatise is his "constructivist" view of international law. He views international law as a "social

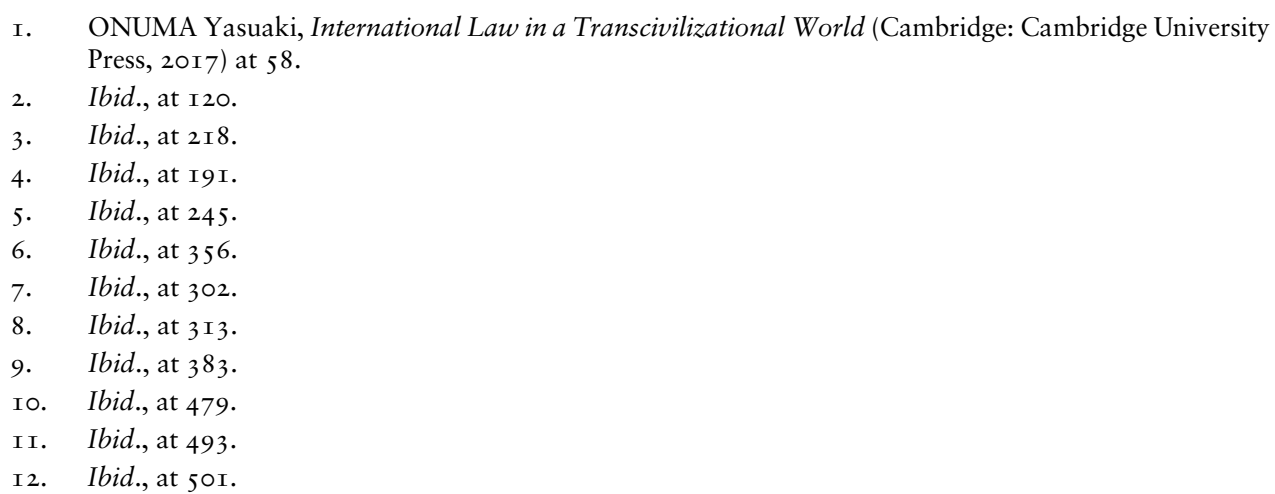


institution" constructed by "participants' cognitive and constructive activities", ${ }^{\mathrm{I}}$ wherein argumentative power relies more on "substantive legitimacy". ${ }^{\text {I4 }}$ Its "diverse societal functions", including "prescriptive, adjudicative, justificatory, legitimating, communicative, value declaratory and constructive (or constitutive) functions", ${ }^{15}$ are, he shows, underestimated in traditional analyses. He is correct but, though he treats the power variable later, he does not operate from a theory of social processes that balances its focus on power and authority.

Professor Onuma frames these socially constructed legal norms as "functionally oriented and context- and forum-dependent". ${ }^{16} \mathrm{He}$ explores various cognitive bases for legal norms to counter arguments that international law is indeterminate. ${ }^{17}$ But he criticizes other concepts such as "sources of law", ${ }^{18}$ customary law, ${ }^{\text {19 }}$ and other "Western-centric" views of law. ${ }^{20}$ For him (as for us) international law goes far beyond the overly limited judicial-centric domestic model-based formulation of international law. In international trade, the $\mathrm{WTO}^{2 \mathrm{I}}$ and commercial arbitration treaties ${ }^{22}$ commonly (and, for Onuma, problematically) use jurisprudence to settle disputes. However, the international judiciary's role in conflict resolution is "limited and weak". ${ }^{23}$ Non-judicial responses are much more common. ${ }^{24}$ Conflicts, such as ones over maritime matters, are mostly "prevented, managed and solved through diplomatic negotiations, where international law functions as a prescriptive, communicative, justifying and legitimating tool". ${ }^{25}$

Professor Onuma critiques others who argue that international law is chimerical and unenforceable by comparing it to domestic law, where some laws are broken but nevertheless remain laws. ${ }^{26}$ It is not the most robust defence of the effectiveness of international law. But non-enforcement is not everything: he points to the legal and political costs for breaking international legal norms, ${ }^{27}$ such as social pressure, ${ }^{28}$ counter-measures, ${ }^{29}$ etc. However, naming and shaming can backfire when engaging non-Western countries in human rights diplomacy. ${ }^{3 \circ}$ Instead, Onuma argues that the

\footnotetext{
I3. Ibid., at I20.

I4. Ibid., at III.

I 5. Ibid., at 30 (emphasis removed).

I6. Ibid., at I I I (emphasis removed).

I7. Ibid., at Io6.

I8. Ibid., at I05.

I9. Ibid., at I 58 .

20. Ibid., at I78-9.

2I. Ibid., at 445 .

22. Ibid., at 456 .

23. Ibid., at 252.

24. Ibid.

25. Ibid., at 328 .

26. Ibid., at 39 .

27. Ibid., at 40 .

28. Ibid., at 129 .

29. Ibid., at 289.

30. Ibid., at $4 \mathrm{I} 4$.
} 
"North Wind and the Sun" approach of integrating beneficial and coercive policies works best. ${ }^{3 \mathrm{I}}$

Like the New Haven school, Onuma believes that traditional conceptions of international law have also inordinately focused on states, ${ }^{32}$ excluding important non-state participants who help construct and maintain international legal norms. ${ }^{33}$ The primary subject and secondary subject grouping of international law "lacks a coherent factual basis". ${ }^{34}$ Furthermore, the Western-centric approach of international law diminishes its global legitimacy. ${ }^{35}$ Because socially constructed legal norms of international law are only effective with broad buy-in, the Western-centric approach should be replaced by a transcivilizational perspective, the key thrust of the book.

For Onuma, a transcivilizational perspective is a "cognitive and evaluative framework based on the recognition of the plurality of civilizations and cultures that have long existed", ${ }^{6}$ including "intra-civilizational diversity" and "inter-civilizational cultures". ${ }^{37}$ It would recognize international agreements created by an overwhelming majority of states as the collective "normative consciousness". ${ }^{38}$ Importantly, it would include non-state perspectives, ${ }^{39}$ especially those of minorities, ${ }^{40}$ indigenous peoples, ${ }^{4 \mathrm{I}}$ and other marginalized peoples. A transcivilizational perspective, if adopted, would diminish the feeling of marginalization in non-Western people that hurts interstate relations, ${ }^{42}$ impedes acceptance of human rights values, ${ }^{43}$ and contributes to terrorism. ${ }^{44}$

The transcivilizational perspective is not only a defence against Western dominance; it also will contain coming realignments in economic and military material power relations. ${ }^{45}$ Traditional international law analyses have not sufficiently acknowledged the "strong sense of humiliation" that characterizes many non-Western nations whose power is on the rise. ${ }^{46}$ And in fact, one such nation, China, may be seeking to reshape the international order based on its historical egocentric idea of the tributary system. ${ }^{47}$ Scholars have overlooked this and other non-Western historical normative systems. ${ }^{48}$

\footnotetext{
3I. Ibid., at 4I3, 649 .

32. Ibid., at 283 .

33. Ibid., at I9I.

34. Ibid., at 189 (emphasis removed).

35. Ibid., at 54 .

36. Ibid., at 19.

37. Ibid., at I9, n 4 .

38. Ibid., at I 57

39. Ibid., at I70.

40. Ibid., at 237 .

4I. Ibid., at 239.

42. Ibid., at 657 .

43. Ibid., at 375 .

44. Ibid., at 637 .

45. Ibid., at $3 \mathrm{I}$.

46. Ibid., at 359 .

47. Ibid., at $5, \mathrm{n}_{4}$.

48. Ibid., at 56 .
} 
Finally, Onuma asserts that the socially constructed legal norms of international law themselves need to be reworked to guarantee equality and morality. A law itself may be "unjust in its content and function". ${ }^{49}$ For Onuma, a transcivilizational perspective is a good start to ensuring that all voices are heard. International law practitioners need to be more involved in "revealing unjust or illegitimate normative realities and [in] proposing alternative realities to be socially structured for a better, or at least less evil, world".$^{\circ}$

Professor Onuma's grievances are not confined to the horizontal Eastern-Western plane; they also extend to the disparity between the rich and the poor, asymmetric power relations between nations, contrasts between developing or socialist nations and "Western capitalist nations", and hurtful Western-centrism that overlooks nonWestern values.

For example, he lists stringent intellectual property [IP] rights as a factor that hurts the poor in favour of the rich, but passes over the economic strategy that underpins the construct of intellectual property. ${ }^{5 \mathrm{I}} \mathrm{He}$ believes arbitration can favour Western countries over non-Western ones ${ }^{52}$ without taking account of the advantage that the frequent user enjoys in any mode of dispute resolution. Conditions on aid and loans are another issue that can unfairly hurt poorer borrower states. ${ }^{53}$ In Onuma's view, human rights practitioners should focus on developing socioeconomic rights, not adhere to the dated "liberty-centric" prioritization of civil and political rights. ${ }^{54}$

He repeatedly critiques asymmetric power relationships as harming the equality between nations when discussing topics such as the UN Security Council ${ }^{55}$ or diplomatic protection. ${ }^{56} \mathrm{He}$ argues that developing countries "were compelled to accept the demands of the Western capitalist nations" during the later stages of United Nations Convention on the Law of the Sea [UNCLOS] negotiations ${ }^{57}$ but mostly passes over the considerable protections which smaller and weaker states secured. For Onuma, the predominant deregulatory ideology ${ }^{58}$ encourages economic exploitation by giant transnational companies ${ }^{59}$ through tools such as the International Centre for Settlement of Investment Disputes [ICSID], “a 'triumph' of the global capitalist ideology". 60 "Casino capitalism" has run amuck. ${ }^{6 \mathrm{I}}$ However, he does mention that the psychology of blame without responsibility is the fundamental cause of developing countries' failures. ${ }^{62}$

\footnotetext{
49. Ibid., at 25 .

50. Ibid., at 26 .

5I. Ibid., at 439 .

52. Ibid., at 454-5.

53. Ibid., at 472 .

54. Ibid., at 383 .

55. Ibid., at 95 .

56. Ibid., at 346 .

57. Ibid., at $325, \mathrm{n} 3 \mathrm{I}$.

58. Ibid., at 479 .

59. Ibid., at 450.

6o. Ibid., at 455 .

6I. Ibid., at 460, n 45 .

62. Ibid., at $657, \mathrm{n} 58$.
} 
Finally, he decries Western-centric modernity influenced by "racism, male-centrism, state-centrism" and Christianity-centrism. ${ }^{63}$ Western governments, NGOs, and influential media that criticize non-Western cultures are seen as "self-righteous", "hypocritical", ${ }^{64}$ and exercising a "double standard". ${ }^{65}$ Western-centric secular and materialistic values also destroy the environment. ${ }^{66} \mathrm{He}$ believes international law should protect future generations by relying on "social ethics or religion", such as by incorporating "non-legalistic, yet normatively deep and universally appealing” Buddhist ideas or the respect for nature found in animism. ${ }^{67}$

\section{III.}

Civilizations are awkward, rather unmanageable candidates for representation in international institutions, especially in an era concerned with the protection of individual human rights. Although Onuma rightfully highlights many class and gender disparities throughout his work, in a time when equitable class and gender representation in decision-making is demanded and, at the United Nations, diversity is measured in terms of regional representation, the focus on civilizations seems very retro. And not necessarily democratic! Civilization's philosophic heyday was reflected in the work of Burke, Rousseau, and, of course, Hegel, who was of the view that "not all peoples are to be counted among the welthistorische Volksgeister" ${ }^{68}$

Less nasty, but still in the game of selecting winners and losers among competing civilizations, is Article 9 of the Statute of the International Court of Justice; it admonishes electors in the Security Council and General Assembly to be mindful "that in the body as a whole the representation of the main forms of civilization and of the principal legal systems of the world should be assured". ${ }^{69}$ Statute Article 38(I)(c) is more explicitly judgmental, confining the class of contributors to the formation of "general principles" to "civilized nations". ${ }^{70}$ That these are now viewed uneasily as anachronisms does not negate the fact that, for a transcivilizationist approach, not all civilizations nor all practices of a given civilization are acceptable; some other values, which are not the result of a transcivilizationist canvassing, are determinative.

The point is that even deploying transcivilizationism as a working method requires extra-civilizational criteria. Unless one takes, for all civilizations, Herder's position that a civilization is fixed ("Germany had always had and would always have 'a fixed national spirit"”), ${ }^{7 \mathrm{I}}$ the decision-makers trying to identify the values of a civilization would find themselves caught in Savigny's dilemma: at what point has a particular

\footnotetext{
63. Ibid., at 366 .

64. Ibid., at $36 \mathrm{I}$.

65. Ibid., at 373 .

66. Ibid., at 529 .

67. Ibid., at 532 .

68. George H. SABINE, A History of Political Theory, 3 rd rev. ed. (London: Harrap, I963) at 630.

69. Statute of the International Court of Justice, art. 9 (emphasis added).

70. Statute of the International Court of Justice, art. 38 , para. I(c).

7I. Sabine, supra note 68.
} 
practice of a civilization reached its highest state and, thus, is ripe for canonization, rather than still in a stage of gestation? ${ }^{72}$

Professor Onuma does not wrestle with these issues. For him, transcivilizationism seems to have some nearly magical properties that can bring contending parties together. Even in win-win outcomes, some winners win more: while laws always benefit some more than others and, hence, are always under stress to change, transcivilizationist law produces decisions, legislative and applicative, to which everyone, winners and losers, will be more likely to be reconciled. This is redolent of jurisprudential alchemy and even if it works (which we doubt), Professor Onuma himself acknowledges that it will not infallibly produce good decisions, so how does one determine goal values that serve to assess current options and provide a lodestar for future action? And, bearing in mind that historicist approaches to law look backwards, how does one do this for challenges for which past experience may provide little relevance? In trying to game out how Onuma's approach would work in a near global science-based and technological civilization that is replete with possibilities and problems that were heretofore scarcely imaginable, transcivilizationism often becomes a meme for some sort of collective historicism, ransacking (at least in theory) ancient troves of cultures for answers to problems they never encountered, and that require, for their solution, looking far ahead, all the while filtering out those hideous elements that have fortunately been acknowledged and repudiated. In fairness, Onuma acknowledges that, even if it works, a transcivilizationist methodology may not produce harmony, which is no surprise, for the values of different civilizations may be very different. But, if so, what truly transcivilizational values will then serve to guide decisions?

International human rights codes do not provide a ready answer for Onuma, for they are plagued by a "Western" conception of individual dignity imposed on a diverse world..$^{73}$ In order to universalize the idea of human rights, Onuma seeks to unmoor it from its roots in individual human dignity. This seems to be too hasty a dismissal. It is easy to understand the indignation of those on the receiving end of several centuries of invasion and control. But the concept of human dignity, from Pico de Mirandola, through the Reformation, Westphalia, the Industrial Revolution, and so on, has given rise to the modern human rights movement, which has ignited a never-ending quest that could function as a jus cogens. To pretend to dismiss something valuable because of its origin seems capricious, especially if there is no ready alternative.

IV.

But, these criticisms aside, Professor Onuma is, in principle, correct: criteria are required for appraising existing international legal arrangements and for constructing

72. See W. Michael REISMAN and Aaron M. SCHREIBER, Jurisprudence: Understanding and Shaping Law (New Haven, CT: New Haven Press, I987) at 224-3 I.

73. In reading and discussing Professor Onuma's impressive treatise, we recalled an event from the early I970s that has become part of Yale folklore. Professor Myres McDougal, lecturing to a large class, stated that the goal of international law was to secure human dignity. An American student accused McDougal of simply taking an American concept and imposing it on the rest of the world. Eisuke Suzuki of Tokyo, a doctoral student, who is remembered for having founded the Yale Journal of International Law by using his own fellowship money and living in his car, bounded angrily out of his chair and shouted: "How dare you claim that America invented human dignity!" 
future arrangements. It is insufficient to distil them from existing institutions and arrangements because they are imprinted with power relationships and interests and, in a deeper sense, with the idiosyncratic values of dominant actors and their elites. If we do not address this challenge, the new masters, waiting in the wings, will simply imprint their own values so that, as in Orwell's Animal Farm, the only change will be in personnel and vocabulary. Distilling the essence of the new or old masters will simply replicate them. International law needs an external set of values to serve as a fulcrum.

The idea of transcivilizationism for that function seems attractive, for, in theory, it allows for great inclusiveness-as long as all the civilizations are represented and all the cultures of minorities, marginalized peoples, and the great losers of history, indigenous peoples, are also taken into account. But we wonder whether there is a method that can make transcivilizationism a meaningful and operational method for goal clarification and not just for a type of preambular slogan that appeases the sense of exclusion of the downtrodden. Even if a massive cultural anthropological research venture could be mounted and could produce a single value or concept, such as "mother earth", would it be more than a slogan, when the challenge would be the reconstruction of a world constitutive process vouchsafing the maintenance of global security, the global production and distribution of wealth, the global shaping and sharing of enlightenment and skill, well-being, respect, and rectitude. Can transcivilizationism really function as a goal clarification method?

In our view, meaningful goal clarification for the international legal scholar first requires an ongoing process of self-scrutiny to identify latent preferences held at levels of consciousness so deep that the self is unaware of them. The New Haven School proposes as the optimum standpoint "that of an individual committed to the common interests of the most inclusive system of world public order" ${ }^{74}$ Common interests are to be expressed in terms of the production and distribution of all scope values, and they are posited and not derived from civilizations or religious texts. In each context, projections of likely future trends are essayed. If those futures bode unsatisfactory results, alternatives may then be invented to achieve a better value production and distribution within the requirements of minimum order.

This is how we envision the role of the complete international legal scholar in the twenty-first century. Of course, the role of scholar is not the only one that international lawyers are called upon to play. As for those negotiating on behalf of a state, though their professional role may require them to champion the interests of their clients, we would suggest that even they would do well to leave their respective civilizations at the door and to focus their efforts, instead, on crafting arrangements that promise the achievement of common interests in terms of value production and sharing. Otherwise, negotiations between one actor charged with devotion to Sharia and his counterpart with an equally passionate reverence for the Bhagavad Gita, one alight with ultramontane Christian fervour and her counterpart with Animism or Stoicism, will have a lot to get around before they can find common ground.

74. W. Michael REISMAN, The Quest for World Order and Human Dignity in the Twenty-first Century: Constitutive Process and Individual Commitment (Leiden: Brill, 2013) at 437. 